p. 166 保除街生 作青学 研 旯 15-5

\title{
22. わが国の平均奉命の推移と死因措造の变化に関する保健学的研究（その2）
}

東北学院大学 安 济 哲 夫

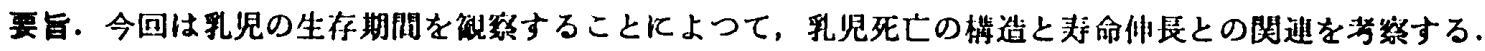

1. 生存期間からみた乎児死亡について

秏児死亡の西因をみると，4週末满とくに 1 週未满の早期新生児死しは先天的なるのが多いが，生存期間が比枚的 長くなると疾病や事故など後天的なものが多くなる．後天的なるのはその防止が割合容易であつて，わが国の改萻も この段階から始まつた．すなわち，昭22年を100とした指数でるると42年は19.4て，しかも生存期間が長いものはど改斯

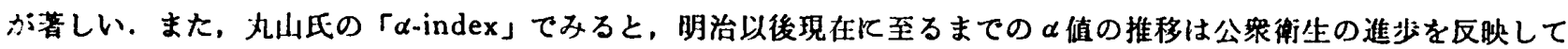

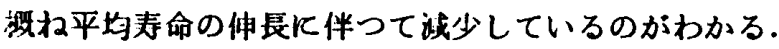

2. 乎児死亡の原因について

その 1 つは出生前と出生時による先天的なもの，他の 1 つは出生後に上る後天的なものであか，わか国のこれら

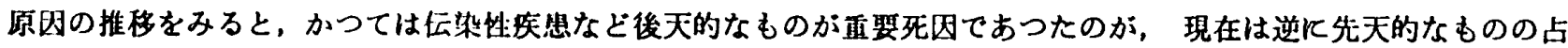

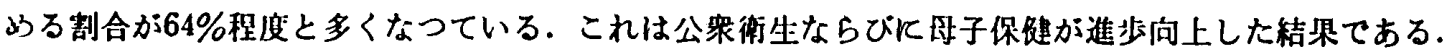

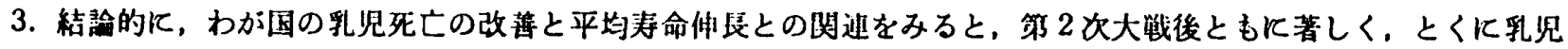
死亡济が60台から30台以下に半淢した26年には丰命も男女とも60才を超えたのである.

以上

\section{3. 迋動の目标設定に閃する一考察 そのI}

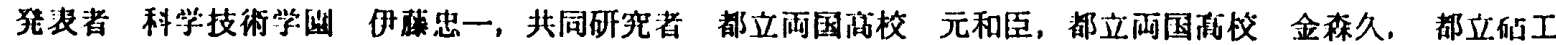

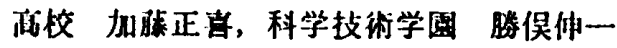

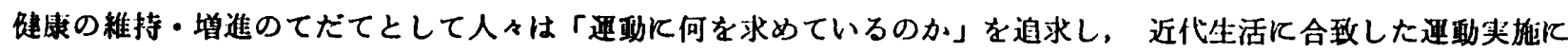

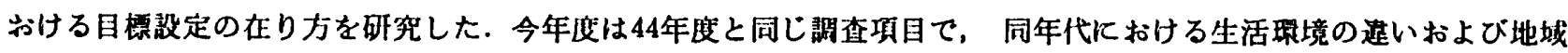

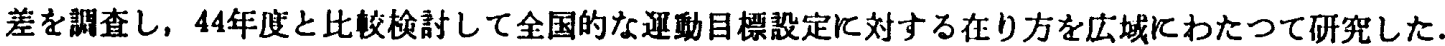

調查項目は身体的効果 10 項目，精种的効果 13項目，社会的效果 12項目を設定して五者択一を用いて，高等学 玟 2 年在学生を対象飞調查を实施した.

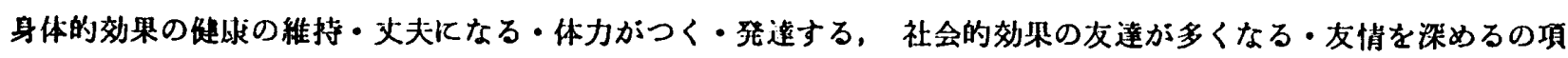

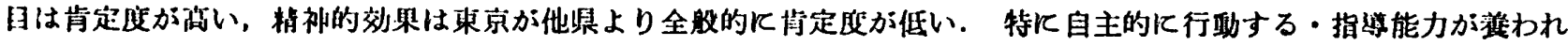

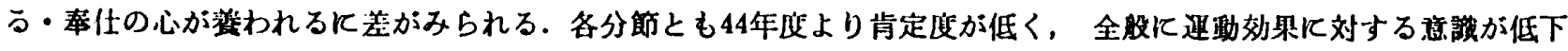
し，学枚租别間（全定普工通）の差がせばまり生活棵境による相僬も当初の予测よりすくないことがわかつた．交通

- 通信の覴及発逢によつて地域の特性は消失の倾向にあると思われる。

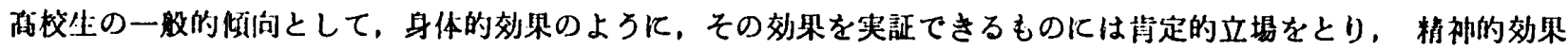

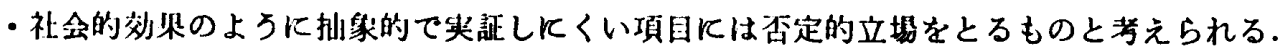

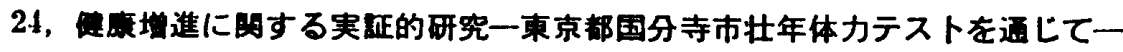

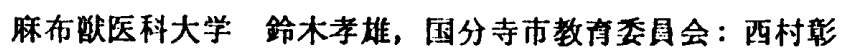

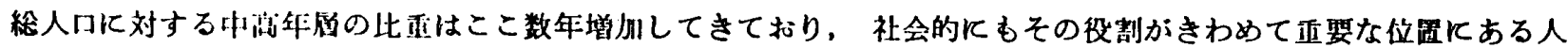

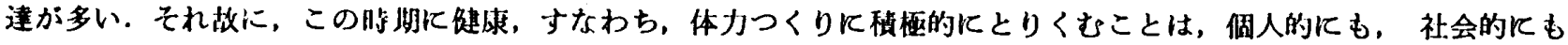

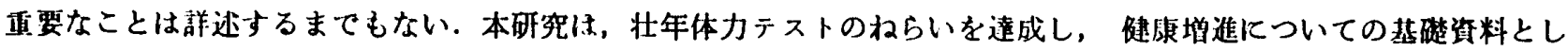

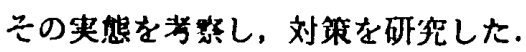

対象及び期日，国分寺行々民 壮年虐 1.12 名，昭和44年 9 月〜11月.

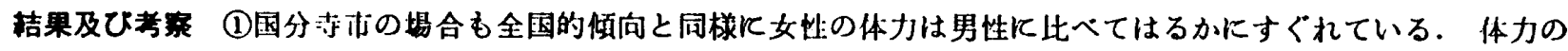

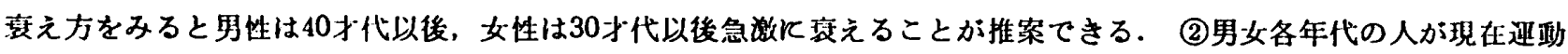

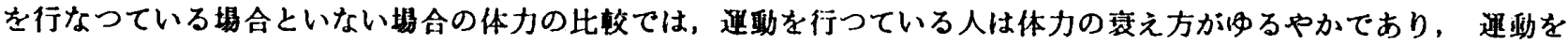
行つていない人の体力は急湤に琵えることができる。

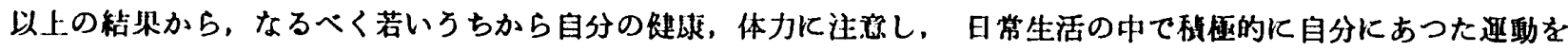
行つていくことが必姴ており，それが，内体面，精神面の早老を子䏚し，健康で活動的な生活がてきることを的束し ます。 